\title{
The effect of cytokinins in vitro on the growth and development of Elatior begonias (Begonia Elatior-hybr.)
}

\author{
PÄIVI ROIVAINEN \\ Department of Horticulture, University of Helsinki, \\ SF-00710 Helsinki
}

\begin{abstract}
Micropropagation involves the risk of somaclonal variation among the regenerated plants. It is possible that the components of the nutrient medium, especially growth substances, increase the frequency of variation.

Elatior Begonia 'Barbara' plants were micropropagated using four cytokinins (zeatin 0.5-2.0 $\mathrm{mg} / \mathrm{l}$, kinetin $0.5-2.0 \mathrm{mg} / \mathrm{l}$, IPA $0.5-2.0 \mathrm{mg} / 1$ or BAP $0.05-0.65 \mathrm{mg} / \mathrm{l}$ ) in vitro. The number of shoots produced per explant and the subsequent quality of full-sized, flowering plants were studied.

In general, the number of big $(>1 \mathrm{~cm})$ and medium-sized $(0.5-1.0 \mathrm{~cm})$ shoots decreased and the number of small $(<0.5 \mathrm{~cm})$ shoots increased with increasing cytokinin concentration. The survival rate after transfer in vivo was highest among big shoots $(97 \%)$ and lowest among small shoots $(65 \%)$. Variation in the development time and number of branches, flowers and flowerbuds was observed among plants induced with different cytokinins at different concentrations. The shortest development time, the lowest number of branches and the highest number of flowers and flowerbuds (= best quality) were obtained with $0.5 \mathrm{mg} / 1 \mathrm{kinetin}$.
\end{abstract}

Index words: Begonia Elatior-hybr., cytokinin, micropropagation, somaclonal variation

\section{Introduction}

Micropropagation is an efficient means of producing plantlets of Elatior begonia. This propagation technique does, however, involve the risk of somaclonal variation. There are only few reports on the tissue culture of Elatior begonias which give information about the uniformity of the regenerants (HILDING and Welander 1976, MikKelsen and Sink 1978, Reuther 1980, Bigot 1981, Roest et al. 1981, TaKayama and Misawa 1982, Westerhof et al. 1984). According to Roest et al. (1981) and Westerhof et al. (1984), differences exist between cultivars of Elatior begonia in the propensity to somaclonal variation. WeSTERHOF et al. (1984) report that the regenerants from the first propagation cycle are uniform, but further subculture increases the frequency of variation, e.g. late flower- 
ing and extreme branching. This has been described also by RoIvAINEN (1987).

It is possible that the components of the nutrient medium, especially growth substances, increase the frequency of somaclonal variation in regenerated plants (MEINS 1983, KARP and Bright 1985, Evans and Bravo 1986, LeE and PHILliPs 1988). There are no reports on the impact of growth substances in the nutrient medium on somaclonal variation in Elatior begonias. However, VARGA et al. (1988) observed a greater proportion of variant (fasciated) plants of Kalanchoe blossfeldiana v. Poelln. when the concentrations of auxins (IAA, IBA and 2,4-D) and cytokinins (zeatin, kinetin and IPA) in the nutrient medium were increased. There were differences also between auxins and cytokinins in the frequency of variation detected.

The aim of this study was to investigate the impact of four commercially used cytokinins in different concentrations in vitro on the number of shoots produced per explant and on the subsequent quality of full-sized, flowering Elatior begonias.

\section{Materials and methods}

Commercially micropropagated Elatior begonia 'Barbara' plants were used as mother plants. They were potted in January 1988 in ST B2-peat (medium coarse Sphagnum peat containing $1.1 \mathrm{~kg} / \mathrm{m}^{3}$ of ST-fertilizer and 8 $\mathrm{kg} / \mathrm{m}^{3}$ of dolomite lime), grown at a night temperature of $18^{\circ} \mathrm{C}$ and fed once a week using a $0.1 \%$ solution of a fertilizer containing $14 \% \mathrm{~N}, 5 \% \mathrm{P}, 21 \% \mathrm{~K}$ plus micronutrients. They were given supplementary lighting (SON/T $400 \mathrm{~W}$, Phillips) of about 5000 lux for 16 hours per day. The plants were at a vegetative stage when the petioles of young leaves were collected as explant material in March 1988.

The petioles were surface sterilized by a quick dip into a $70 \%$ solution of ethanol, followed by $10-15 \mathrm{~min}$ in a solution of $\mathrm{NaOCl}$ $(1 \%$ active $\mathrm{Cl}$ ). Thereafter the petioles were rinsed three times with sterile, distilled water.
The petioles were cut into 5-mm long cylinders and placed in test tubes containing $10 \mathrm{ml}$ of nutrient medium. The basal nutrient medium contained halfstrength Murashige and Skoog major and minor elements (iron added as a chelate, Fe-Na-EDTA), nicotinic acid 0.5 $\mathrm{mg} / \mathrm{l}$, thiamine- $\mathrm{HCl} 0.1 \mathrm{mg} / \mathrm{l}$, pyridoxine- $\mathrm{HCl}$ $0.5 \mathrm{mg} / \mathrm{l}$, glycine $2 \mathrm{mg} / 1$, myoinositol 100 $\mathrm{mg} / \mathrm{l}$, sucrose $30 \mathrm{~g} / \mathrm{l}$ and agar $8 \mathrm{~g} / \mathrm{l}$. A constant level of $0.1 \mathrm{mg} / 1$ of NAA was added to four cytokinins at four different concentrations:

zeatin $0.5,1.0,1.5$ or $2.0 \mathrm{mg} / 1$

kinetin

IPA

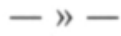

BAP

$$
0.05,0.25,0.45 \text { or } 0.65 \mathrm{mg} / 1
$$

The explants ( 40 per treatment) were grown at $22-26^{\circ} \mathrm{C}$ at a lighting of about 2000 lux (Airam 'cool white' $40 \mathrm{~W}$ fluorescent tubes) for 16 hours a day. After seven weeks, 10 explants with a cluster of shoots were dissected vertically into four segments which were placed on $30 \mathrm{ml}$ of the hormone-free nutrient medium in a $100 \mathrm{ml}$ Erlenmayer flask. After five weeks in the same circumstances as above, the shoots were harvested, graded according to size into small $(<0.5 \mathrm{~cm})$, medium $(0.5-1.0 \mathrm{~cm})$ and big $(>1.0 \mathrm{~cm})$ shoots, and the number of medium-sized and big shoots was counted. The number of small shoots was only estimated.

The base of forty (40) shoots per treatment was dipped into commercial rooting powder (Floramon A, contains $0.1 \%$ of NAA) and planted in Hortus 'Cultoplant' paperpots containing a mixture of peat $(75 \%)$, rockwool $(20 \%)$ and vermiculite $(5 \%)$. An additional experiment comparing the survival rates of shoots treated with Floramon A and untreated shoots was arranged, using 24 extra mediumsized shoots in both treatments.

The planted shoots were placed in a mist frame for 10 days and then transferred into plastic propagators and weaned during one week. Four weeks after transfer in vivo, the survival rate of plantlets was recorded and 15 
of the best growing plantlets from each treatment were potted in the beginning of July 1988 in 12-cm plastic pots using ST B2-peat. The plantlets were grown in natural long day (summertime) at a night temperature of $18^{\circ} \mathrm{C}$. They were given a short-day treatment of two weeks in the end of August during which the daylength was 8 hours. After this the plants were lighted with incandescent lamps at 04.0008.00 hours and at $16.00-20.00$ hours to enhance the formation of flowers.

Fertilization was begun two weeks after transfer in vivo. A fertilizer containing $14 \%$ $\mathrm{N}, 5 \% \mathrm{P}, 21 \% \mathrm{~K}$ plus micronutrients was used. Before potting, the plantlets were fed three times a week using a $0.025 \%$ solution and after potting once a week using a $0.1 \%$ solution.

A completely randomized design was used in the greenhouse with 15 replications. The sale stage was determined when six flowers were open. The plant height was measured from the pot rim to the highest peak of the leaves, and the number of branches was counted at the base of the plant.

Some plants ( $0-2$ per treatment) displayed symptoms which were suspected to be of viral origin, e.g. crinkled leaves and petals. Pathological tests like the double diffusion test and DAS-ELISA were made at the Department of Plant Pathology, University of Helsinki, but no virus was identified. Plants showing the above symptoms were excluded.

\section{Results}

\section{Yield of shoots per explant}

In general, the number of big and mediumsized shoots decreased and the number of small shoots increased with increasing cytokinin concentration (Table 1). However, this trend was not as clear when BAP was used. The highest total number of big and mediumsized shoots was achieved with $0.05 \mathrm{mg} / \mathrm{l}$ BAP.

\section{Survival rate of shoots}

The survival rate was highest among big shoots (97\%) and lowest among small shoots

Table 1. The effect of zeatin, kinetin, IPA and BAP at different concentrations on the number of shoots formed on a leaf petiole explant of Elatior begonia 'Barbara'.

\begin{tabular}{|c|c|c|c|c|c|c|}
\hline \multicolumn{3}{|c|}{ Cytokinin } & \multicolumn{3}{|c|}{$\begin{array}{l}\text { Number of shoots of different } \\
\text { sizes per explant }\end{array}$} & \multirow{2}{*}{$\begin{array}{l}\text { The total number } \\
\text { of big and medium- } \\
\text { sized shoots }\end{array}$} \\
\hline & & & $<0.5 \mathrm{~cm}$ & $0.5-1.0 \mathrm{~cm}$ & $>1 \mathrm{~cm}$ & \\
\hline \multirow{4}{*}{$\begin{array}{c}\text { Zeatin } \\
\quad " \\
" \\
"\end{array}$} & $0.5 \mathrm{r}$ & $\mathrm{mg} / 1$ & $5-10$ & 3.9 & 6.9 & 10.8 \\
\hline & 1.0 & $"$ & $10-20$ & 5.3 & 1.3 & 6.6 \\
\hline & 1.5 & $" n$ & $>20$ & 1.7 & 0.2 & $1.9^{* *}$ \\
\hline & 2.0 & $"$ & $>20$ & 1.9 & 0 & $1.9^{* *}$ \\
\hline \multirow{4}{*}{$\begin{array}{c}\text { Kinetin } \\
" \\
" \\
"\end{array}$} & $0.5 \mathrm{r}$ & $\mathrm{mg} / 1$ & $10-20$ & 6.7 & 3.1 & 9.8 \\
\hline & 1.0 & $"$ & $10-20$ & 5.3 & 1.4 & 6.7 \\
\hline & 1.5 & $n$ & $>20$ & 3.1 & 0.3 & $3.4^{* *}$ \\
\hline & 2.0 & $n$ & $>20$ & 1.9 & 0 & $1.9^{* *}$ \\
\hline \multirow{4}{*}{$\begin{array}{c}\text { IPA } \\
" n \\
" \\
"\end{array}$} & $0.5 \mathrm{r}$ & $\mathrm{mg} / 1$ & $5-10$ & 7.5 & 4.4 & 11.9 \\
\hline & 1.0 & $"$ & $10-20$ & 5.9 & 0.9 & 6.8 \\
\hline & 1.5 & $"$ & $>20$ & 2.3 & 0 & $2.3^{* *}$ \\
\hline & 2.0 & $"$ & $>20$ & 3.7 & 0 & $3.7^{* *}$ \\
\hline \multirow{2}{*}{$\begin{array}{c}\text { BAP } \\
n\end{array}$} & $0.05 \mathrm{r}$ & $\mathrm{mg} / 1$ & $5-10$ & 9.2 & 3.5 & $\underline{12.7}$ \\
\hline & 0.25 & $n$ & $>20$ & 4.7 & 0.4 & 5.1 \\
\hline$"$ & 0.45 & $"$ & $>20$ & 3.5 & 3.8 & 7.3 \\
\hline$"$ & 0.65 & $n$ & $>20$ & 3.9 & 2.5 & 6.4 \\
\hline
\end{tabular}

** Mean differs from the underlined mean at $1 \%$ level (Tukey). 
Table 2. The effect of size on the survival rate four weeks after transfer in vivo of micropropagated shoots of Elatior begonia 'Barbara".

\begin{tabular}{lcrl}
\hline Shoot size & $\begin{array}{c}\text { Number of } \\
\text { shoots planted }\end{array}$ & \multicolumn{2}{c}{$\begin{array}{c}\text { Number of } \\
\text { shoots survived }\end{array}$} \\
\hline$<0.5 \mathrm{~m}$ & 101 & 66 & $(65 \%)$ \\
$0.5-1.0 \mathrm{~cm}$ & 303 & 269 & $(89 \%)$ \\
$>1.0 \mathrm{~cm}$ & 236 & 228 & $(97 \%)$ \\
\hline
\end{tabular}

(65\%) (Table 2). The use of rooting powder was found unnecessary, because the survival rate among the untreated shoots was as high as among the ones treated with rooting powder (both $100 \%$ ).

\section{Plant growth}

The shortest time to reach the sale stage (= development time) was observed in plants induced with $0.5 \mathrm{mg} / 1 \mathrm{kinetin}$ and the longest time with $0.25 \mathrm{mg} / 1$ BAP (Table 3). In general, the development time seemed to be longer with IPA and BAP, as compared to kinetin and zeatin. The development time in- creased with increasing concentration of kinetin and IPA. In the plants induced with zeatin and BAP the response was confusing.

The lowest number of branches was observed in plants grown with $0.5 \mathrm{mg} / 1$ kinetin and the highest in plants induced with 2.0 mg/1 IPA (Table 3). The number of branches increased with increasing concentration of kinetin. With other cytokinins there was no such response. There was a positive correlation between the number of branches and the development time $(\mathrm{p} \leq 0.01)$.

There were no differences in plant height between the treatments (Table 3).

The highest number of flowers and flowerbuds was observed in plants induced with 0.5 $\mathrm{mg} / \mathrm{l}$ kinetin and the lowest in plants induced with $2.0 \mathrm{mg} / 1$ IPA. The number of flowers and flowerbuds decreased with increasing concentration of zeatin and IPA. With kinetin there was no response and with BAP the response was confusing. A reduction was noticed in the size of flowers $(33-100 \%$ of plants, irrespective of treatment) and in the number of petals $(7-27 \%$ of plants, irrespec-

Table 3. The effect of zeatin, kinetin, IPA and BAP at different concentrations on the development time, the number of branches, flowers and flowerbuds and on the height of micropropagated Elatior begonia 'Barbara'.

\begin{tabular}{|c|c|c|c|c|c|c|}
\hline Cytokin & & & Development & Number of & Number of & Height \\
\hline Zeatin & 0.5 & $\mathrm{mg} / \mathrm{l}$ & $105.6^{\mathrm{ab}{ }^{x}}$ & $9.6^{\mathrm{ab} *}$ & $34.0^{a}$ & $20.8^{\mathrm{a}}$ \\
\hline$"$ & 1.0 & $"$ & $105.3^{a}$ & $8.1^{\mathrm{ab}}$ & $29.9^{\mathrm{a}}$ & $19.7^{\mathrm{a}}$ \\
\hline$n$ & 1.5 & $"$ & $110.8^{\mathrm{b} * *}$ & $9.6^{\mathrm{a} *}$ & $28.9^{\mathrm{a} *}$ & $20.1^{\mathrm{a}}$ \\
\hline$"$ & 2.0 & $"$ & $105.4^{\mathrm{ab}}$ & $7.6^{\mathrm{b}}$ & $28.7^{\mathrm{a} *}$ & $19.5^{\mathrm{a}}$ \\
\hline Kinetin & 0.5 & $\mathrm{mg} / \mathrm{l}$ & $\underline{101.0^{\mathrm{a}}}$ & $\underline{7.5}^{\mathrm{a}}$ & $\underline{34.8^{\mathrm{a}}}$ & $20.5^{\mathrm{a}}$ \\
\hline$"$ & 1.0 & $"$ & $\overline{105.8^{a b}}$ & $\overline{9.4}^{\mathrm{ab}}$ & $\overline{33.6^{a}}$ & $20.7^{\mathrm{a}}$ \\
\hline$n$ & 1.5 & $"$ & $105.4^{\mathrm{ab}}$ & $9.6^{6 *}$ & $34.4^{\mathrm{a}}$ & $21.0^{a}$ \\
\hline$"$ & 2.0 & $"$ & $106.2^{\mathrm{b*}}$ & $10.1^{\mathrm{b} * *}$ & $33.3^{\mathrm{a}}$ & $20.4^{a}$ \\
\hline IPA & 0.5 & $\mathrm{mg} / \mathrm{l}$ & $107.0^{\mathrm{a} *}$ & $9.6^{\mathrm{a} *}$ & $33.4^{\mathrm{a}}$ & $21.2^{\mathrm{a}}$ \\
\hline$n$ & 1.0 & $"$ & $107.7^{\mathrm{ab} * *}$ & $10.1^{\mathrm{a} * *}$ & 29.9ab & $19.9^{\mathrm{a}}$ \\
\hline$"$ & 1.5 & $"$ & $113.0^{b * *}$ & $9.7^{a *}$ & $27.1^{b * *}$ & $19.2^{\mathrm{a}}$ \\
\hline$"$ & 2.0 & $"$ & $112.1^{b * *}$ & $11.1^{\mathrm{a} * *}$ & $26.6^{\mathrm{b**}}$ & $19.9^{\mathrm{a}}$ \\
\hline BAP & 0.05 & $\mathrm{mg} / \mathrm{l}$ & $109.8^{\mathrm{ac} * *}$ & $9.6^{\mathrm{a} *}$ & $30.1^{\mathrm{abc}}$ & $20.8^{\mathrm{a}}$ \\
\hline$"$ & 0.25 & $"$ & $119.7^{b * *}$ & $9.1^{\mathrm{a}}$ & $27.0^{2 * * *}$ & $21.0^{a}$ \\
\hline$n$ & 0.45 & $"$ & $106.1^{\mathrm{c*}}$ & $9.5^{\mathrm{a} *}$ & $33.9^{\mathrm{b}}$ & $20.1^{\mathrm{a}}$ \\
\hline$"$ & 0.65 & " & $114.6^{\mathrm{ab} * *}$ & $9.5^{\mathrm{a} *}$ & $26.9 \mathrm{ac**}$ & $20.8^{a}$ \\
\hline
\end{tabular}

2 Means followed by a common letter within one cytokinin do not differ at $5 \%$ level.

* Mean differs from the underlined mean at $5 \%$ level.

** Mean differs from the underlined mean at $1 \%$ level. (Tukey) 
tive of treatment), as compared to normal flowers of 'Barbara'. In 1-2 plants induced with $2.0 \mathrm{mg} / 1$ zeatin, $0.25 \mathrm{mg} / 1 \mathrm{BAP}$, as well as with $0.5,1.5$ or $2.0 \mathrm{mg} / \mathrm{l}$ kinetin, the colour of the flowers had turned to yellowish pink instead of the normal pure pink. One variant with salmon-coloured flowers was observed among the plants grown with $0.5 \mathrm{mg} / 1$ kinetin.

\section{Discussion}

When the cytokinin concentration in the nutrient medium was increased, also the number of shoots formed on the explant increased. This was, however, at the expense of the size of the shoots, as has been reported by SiMMONDS (1984). The growth retarding effect of high cytokinin concentrations could not be counteracted by transferring the shoots to hormone-free medium for five weeks. It would be interesting to know the duration of this growth retarding effect. The shoots grown with high cytokinin concentrations were difficult to handle, not only because of their small size, but also because of the brittleness of the tissue. The survival rate in vivo also depended on the size of the shoots: it was lowest among the small shoots. In commercial propagation, a great number of shoots per explant would be desirable, but small shoots (or rather buds) cannot be utilized for propagation unless a method to enhance their growth can be developed.

Some retardation could be detected in the development of the plant to the floral stage with increasing concentration of kinetin and IPA. This kind of variation could be a reflection of the retarded growth of the shoots used as planting material or some kind of prolonged vegetativeness caused by a reversion to juvenility during the in vitro phase. However, juvenility is usually associated with strong vegetative growth and, in spite of different development times, all plants ended up to approximitely the same size. Anyhow, there was a positive correlation between the development time and the number of branches. This leads to a thought that the delay in flowering is associated with a reduction in apical dominance, possibly caused by an aftereffect of high cytokinin concentration of the in vitro phase. However, the number of branches increased clearly only when the concentration of kinetin was increased. There seem to be differences between cytokinins in regard to these results. VARGA et al. (1988) obtained less fasciated Kalanchoe blossfeldiana v. Poelln. plants using IPA instead of zeatin or kinetin, at concentrations of 1 and $2 \mathrm{mg} / 1$.

A decrease was detected in the number of flowers and flowerbuds when the concentrations of zeatin and IPA were increased. This variation could also be a manifestation of juvenility, and it coincided with the increasing development time with increasing concentration of IPA. A question arose, whether the detected reduction in the flower size and in the number of petals could have been caused by a latent viral infection. Some plants showed viral-like symptoms, but the spread of a possible virus was not investigated in the present experiment.

Of the cytokinins and their concentrations used in this experiment, $0.5 \mathrm{mg} / 1$ kinetin yielded the shortest development time, the lowest number of branches and the highest number of flowers and flowerbuds (= best quality). Another question is whether the total number of big and medium-sized shoots thus produced, 9.8 shoots per explant, is sufficient for commercial purposes. The total number of big and medium-sized shoots can be termed "economical shoot yield" on the basis of easiness of handling of the shoots and their survival rate.

Acknowledgements. The author wishes to thank the Horticultural Foundation of Nikolai and Ljudmila Borisoff, the Research Foundation of Kemira, the Agricultural Research Foundation of Tiura and the Women's Scientific Foundation for financial support. 


\section{References}

Bıcot, C. 1981. Multiplication végétative in vitro de Begonia $\times$ hiemalis ('Rieger' et 'Schwabenland'). II. - Conformité des plantes élevées en serre. Agronomie 6: $441-447$.

Evans, D.A. \& Bravo, J.E. 1986. Phenotypic and genotypic stability of tissue cultured plants. Tissue Culture as a Plant Production System for Horticultural Crops. p. 73-96. The Netherlands.

Hilding, A. \& Welander, T. 1976. Effects of some Factors on Propagation of Begonia $\times$ hiemalis in vitro. Swed. J. Agric. Res. 6: 191-199.

KARP, A. \& BRIGHT, S.W.J. 1985. On the causes and origins of somaclonal variation. Oxford Surv. Pl. Molec. Cell Biol. 2: 199-234.

LeE, M. \& Phillips, R.L. 1988. The chromosomal basis of somaclonal variation. Ann. Rev. Pl. Physiol. 39: 413-437.

Meins, F., Jr. 1983. Heritable variation in plant cell culture. Ann. Rev. Pl. Physiol. 34: 327-346.

Mikkelsen, E.P. \& Sink, K.C., Jr. 1978. In Vitro Propagation of Rieger Elatior Begonias. HortSci. 13: 242244.

Reuther, G. 1980. Elatiorbegonien. I. Weitere Untersuchungen zur Gewinnung von befallsfreien Elitepflanzen durch Gewebekultur. Gb + Gw 80: 876, 880 881.

\section{SELOSTUS}

\section{Ravintoalustaan in vitro lisättyjen sytokiniinien vaikutus pauliinabegonian (Begonia Elatior-hybr.) kasvuun ja kehitykseen}

\section{Päivi Roivainen}

Helsingin yliopisto, puutarhatieteen laitos, $00710 \mathrm{Helsinki}$

Mikrolisăyksen kăyttő kasvien tuotannossa tuo mukanaan somaklonaalisen variaation riskin. On mahdollista, ettă ravintoalustan ainesosilla, erityisesti kasvuaineilla, on variaatiota lisảăvă vaikutus.

Pauliinabegonian 'Barbara'-lajiketta mikrolisăttiin käyttäen neljäă eri sytokiniiniä (zeatiini $0.5-2.0 \mathrm{mg} / \mathrm{l}$, kinetiini $0.5-2.0 \mathrm{mg} / \mathrm{l}$, IPA $0.5-2.0 \mathrm{mg} / 1$ tai BAP $0.05-0.65 \mathrm{mg} / \mathrm{l})$ in vitro. Muodostuneiden versojen mäără sekă tăysikokoisten, kukkivien kasvien laatu havainnoitiin.

Yleisesti ottaen, suurten (pituus $>1 \mathrm{~cm}$ ) ja keskikokois-
Roest, S., Berkel, M.A.E. van, BokelmanN, G.S. \& Broertues, C. 1981. The use of an in vitro adventitious bud technique for mutation breeding of Begonia $\times$ hiemalis. Euphytica 30: 381-388.

RoIvAINEN, P. 1987. The in vivo growth and development of micropropagated Elatior begonias (Begonia $\times$ hiemalis). I. Study on the effect of lighting and substrate. J. Agric. Sci. Finl. 59: 387-396.

Simmonds, J. 1984. Induction, growth and direct rooting of adventitious shoots of Begonia $\times$ hiemalis. Plant Cell, Tissue and Organ Culture 3: 283-289.

Takayama, S. \& Misawa, M. 1982. Factors affecting differentiation and growth in vitro, and a masspropagation scheme for Begonia $\times$ hiemalis. Sci. Hort. 16: $65-75$.

VArGa, A., Thoma, L.H. \& Bruinsma, J. 1988. Effects of auxins and cytokinins on epigenetic instability of callus-propagated Kalanchoe blossfeldiana Poelln. Plant Cell, Tissue and Organ Culture 15: 223-231.

Westerhof, J., Hakkaart, F.A. \& Versluijs, J.M.A. 1984. Variation in two Begonia $\times$ hiemalis clones after in vitro propagation. Sci. Hort. 24: 67-74.

Ms received March 22, 90 ten (pituus $0.5-1.0 \mathrm{~cm}$ ) versojen mäărä pieneni ja pienten (pituus $<0.5 \mathrm{~cm}$ ) versojen măără suureni nousevan sytokiniinikonsentraation myötă. Isoja versoja jäi siirron in vivo jälkeen eloon eniten $(97 \%)$, pieniä versoja vähiten $(65 \%)$. Kehitysajassa sekă haarojen, kukkien ja kukkanuppujen lukumaaărăssă todettiin variaatiota eri sytokiniineillă ja năiden eri konsentraatioilla tuotettujen kasvien välillä. Lyhyin kehitysaika, pienin haarojen lukumäără sekă suurin kukkien ja kukkanuppujen lukumäărä (=paras laatu) saatiin aikaan kinetiinillä, $0.5 \mathrm{mg} / \mathrm{l}$. 